$9-1-2016$

\title{
Leaving Labour Law's Pragmatic and Purposive Fortress Behind: Canadian Union Successor Rights Law as a Case Study
}

Pascal McDougall

Harvard University, pmcdougall@sjd.law.harvard.edu

Follow this and additional works at: https://digitalcommons.osgoode.yorku.ca/ohlj

Part of the Labor and Employment Law Commons

Article

\section{c) (1) $(9)$}

This work is licensed under a Creative Commons Attribution-Noncommercial-No Derivative Works 4.0 License.

\section{Citation Information}

McDougall, Pascal. "Leaving Labour Law's Pragmatic and Purposive Fortress Behind: Canadian Union Successor Rights Law as a Case Study" Osgoode Hall Law Journal 54.1 (2016) : 253-290.

This Article is brought to you for free and open access by the Journals at Osgoode Digital Commons. It has been accepted for inclusion in Osgoode Hall Law Journal by an authorized editor of Osgoode Digital Commons. 


\title{
Leaving Labour Law's Pragmatic and Purposive Fortress Behind: Canadian Union Successor Rights Law as a Case Study
}

\begin{abstract}
In this article, I analyze a series of Canadian cases on union successor rights defining the circumstances in which labour rights should be transferred to a successor entity in the context of business sales, restructuring and subcontracting. My analysis casts doubt on a globally influential theory of legal interpretation, which I call the "old legality." According to this theory, labour law is made not through conventional legal reasoning but through non-legal, pragmatic, and purposive applications of loose industrial relations standards. I claim that the old legality paradigm is analytically inaccurate and has the perverse effect of normalizing the status quo of the post-war labour law regime in a context where its insufficiency is widely acknowledged.

Against the old legality, I propose a new approach to studying and teaching labour law doctrine, which I apply here to union successor rights law. This approach portrays labour law reasoning not as pragmatic and purposive but as riven by continuously recurring and incommensurable legal policy conflicts that render purposive argument inconclusive. I suggest that, by constantly bringing these conflicts to the fore in their research and teaching, labour law academics can contribute to opening up the status quo for normative contestation and help create possibilities for ambitious re-regulation of living conditions in the direction of, say, radical equality, participation, and redistribution.
\end{abstract}

\section{Keywords}

Labor unions--Law and legislation; Labor unions--Recognition; Employee rights; Canada

\section{Creative Commons License}

\section{(c) (i) $(9)$}

This work is licensed under a Creative Commons Attribution-Noncommercial-No Derivative Works 4.0 License.

\section{Cover Page Footnote}

S.J.D. Candidate, Harvard Law School; Law Clerk to Justice Clément Gascon, Supreme Court of Canada (2015-2016). Former Counsel for the Confederation of National Labour Unions (Montreal, Canada). Member of the Quebec Bar and the Canadian Association of Labour Lawyers. LL.M. (University of Toronto); Licence en droit (University of Ottawa). I thank Kerry Rittich, Brian Langille, Benjamin Sachs, Samuel Moyn, Duncan Kennedy, William Alford and Mikhail Xifaras for comments on earlier versions of this article and/or discussions that fed my project. I thank the Social Sciences and Humanities Research Council of Canada for financial support. Errors are mine alone (pmcdougall@sjd.law.harvard.edu). 


\title{
Leaving Labour Law's Pragmatic and Purposive Fortress Behind: Canadian Union Successor Rights Law as a Case Study
}

\begin{abstract}
In this article, I analyze a series of Canadian cases on union successor rights defining the circumstances in which labour rights should be transferred to a successor entity in the context of business sales, restructuring and subcontracting. My analysis casts doubt on a globally influential theory of legal interpretation, which I call the "old legality." According to this theory, labour law is made not through conventional legal reasoning but through non-legal, pragmatic, and purposive applications of loose industrial relations standards. I claim that the old legality paradigm is analytically inaccurate and has the perverse effect of normalizing the status quo of the post-war labour law regime in a context where its insufficiency is widely acknowledged.

Against the old legality, I propose a new approach to studying and teaching labour law doctrine, which I apply here to union successor rights law. This approach portrays labour law reasoning not as pragmatic and purposive but as riven by continuously recurring and incommensurable legal policy conflicts that render purposive argument inconclusive. I suggest that, by constantly bringing these conflicts to the fore in their research and teaching, labour law academics can contribute to opening up the status quo for normative contestation and help create possibilities for ambitious re-regulation of living conditions in the direction of, say, radical equality, participation, and redistribution.
\end{abstract}

\section{Keywords}

Labor unions--Law and legislation; Labor unions--Recognition; Employee rights; Canada

\section{Cover Page Footnote}

S.J.D. Candidate, Harvard Law School; Law Clerk to Justice Clément Gascon, Supreme Court of Canada (2015-2016). Former Counsel for the Confederation of National Labour Unions (Montreal, Canada). Member of the Quebec Bar and the Canadian Association of Labour Lawyers. LL.M. (University of Toronto); Licence en droit (University of Ottawa). I thank Kerry Rittich, Brian Langille, Benjamin Sachs, Samuel Moyn, Duncan Kennedy, William Alford and Mikhail Xifaras for comments on earlier versions of this article and/or discussions that fed my project. I thank the Social Sciences and Humanities Research Council of Canada for financial support. Errors are mine alone (pmcdougall@sjd.law.harvard.edu). 


\title{
Leaving Labour Law's Pragmatic and Purposive Fortress Behind: Canadian Union Successor Rights Law as a Case Study
}

\author{
PASCAL MCDOUGALL*
}

In this article, I analyze a series of Canadian cases on union successor rights defining the circumstances in which labour rights should be transferred to a successor entity in the context of business sales, restructuring and subcontracting. My analysis casts doubt on a globally influential theory of legal interpretation, which I call the "old legality." According to this theory, labour law is made not through conventional legal reasoning but through non-legal, pragmatic, and purposive applications of loose industrial relations standards. I claim that the old legality paradigm is analytically inaccurate and has the perverse effect of normalizing the status quo of the post-war labour law regime in a context where its insufficiency is widely acknowledged.

Against the old legality, I propose a new approach to studying and teaching labour law doctrine, which I apply here to union successor rights law. This approach portrays labour law reasoning not as pragmatic and purposive but as riven by continuously recurring and incommensurable legal policy conflicts that render purposive argument inconclusive. I suggest that, by constantly bringing these conflicts to the fore in their research and teaching, labour law academics can contribute to opening up the status quo for normative contestation

S.J.D Candidate, Harvard Law School. LL.M (University of Toronto); Licence en droit (University of Ottawa). Member of the Barreau du Québec and the Association des juristes progressistes. I thank Kerry Rittich, Brian Langille, Duncan Kennedy, Samuel Moyn,

Benjamin Sachs, William Alford, and Mikhail Xifaras for comments on earlier versions of this article or discussions that fed my project. I thank the Social Sciences and Humanities Research Council of Canada for financial support. Errors are mine alone (pmcdougall@sjd.law.harvard.edu). 
and help create possibilities for ambitious re-regulation of living conditions in the direction of, say, radical equality, participation, and redistribution.

J'analyse dans cet article plusieurs décisions canadiennes sur le transfert des droits syndicaux établissant les modalités selon lesquelles les droits des travailleurs peuvent être transférés à une entité successeure dans le contexte d'une vente d'entreprise, d'une restructuration ou d'une sous-traitance. Ce faisant, je mets en doute une influente théorie d'interprétation juridique que je nomme la « juridicité traditionnelle ». Selon cette théorie, le droit du travail ne procède pas d'un raisonnement juridique conventionnel, mais de l'application non juridique, pragmatique et téléologique de larges normes de relations industrielles. Je soutiens que le paradigme de la juridicité traditionnelle est analytiquement inexact et a l'effet pervers de légitimer le statu quo du régime de droit du travail d'aprèsguerre dans un contexte où son insuffisance est largement reconnue.

Pour remplacer la juridicité traditionnelle, je propose une nouvelle approche à l'étude et à l'enseignement du droit du travail, que j'applique ici au droit relatif au transfert des droits syndicaux. Cette approche dépeint le raisonnement juridique en droit du travail non pas comme pragmatique et téléologique, mais comme déchiré par des conflits de politique juridique récurrents et incommensurables qui rendent inconcluante l'argumentation téléologique. Je suggère qu'en ramenant sans cesse ces conflits au premier plan de leur recherche et de leur enseignement, les chercheurs et professeurs de droit du travail peuvent contribuer à contester le statu quo et tracer la voie vers une ambitieuse réglementation des conditions de vie allant dans le sens, par exemple, d'une égalité, d'une participation et d'une redistribution radicales.

I. ONTARIO SUCCESSOR RIGHTS CASES: FROM METRO-PARKING TO AJAX

II. QUEBEC SUCCESSOR RIGHTS CASES: FROM BIBEAULT TO IVANHOE …………........................ 270

III. READING THE CASES TOGETHER: QUESTIONS OF LAW IN PYRAMIDAL INTERCONNECTION ......274

IV. BEYOND PURPOSE AND PRAGMATISM: MAPPING THE POLICY LANDSCAPE............................... 277

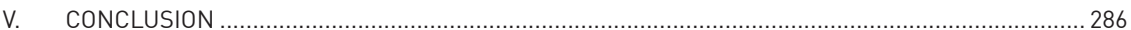

IT IS BY NOW WELL-KNOWN that economic, social, and political shifts in the last forty years have shaken labour and employment law to its foundations in North Atlantic countries. Changing trade and investment flows leading to greater market volatility, increased technological innovation, demographic transformations, increased migration flows, and the declining regulatory capacity of the nation state are all part of these shifts. Whether perceived or real, these changes are said to have rendered post-war collective bargaining and employment standards 
legislation much less effective. ${ }^{1}$ Moreover, in this so-called "new economy," it is said that "corporations have undergone a process of vertical disintegration, morphing into networks of firms and contractors whose constituent parts change as frequently as do the workers that they employ." This "fissuring" of the traditional workplace-the workplace associated with the Fordist post-war economy - has had a tremendous impact on the United States and Canada's Wagner Act collective labour relations model, which is based on local, single employer certification. ${ }^{3}$

Legislative provisions empowering labour adjudicators to protect union successor rights, which deal with cases where the integrity of bargaining rights is allegedly compromised by economic transfers and reorganizations, are of central legal and political importance in this context. ${ }^{4}$ Successor rights provisions are specifically intended to empower labour boards to preserve bargaining rights and the ability to associate, bargain collectively, and strike in the face of economic reorganizations and employer attempts to undermine bargaining structures. Under such provisions, labour adjudicators can transfer union certifications and collective agreements to new "successor" entities such as a subcontractor that

1. See generally Richard Freeman, "The Great Doubling: The Challenge of the Growing Globalization of Labor Markets to Economic and Social Policy" in Eva A Paus, ed, Global Capitalism Unbound: Winners and Losers from Offshore Outsourcing (New York: Palgrave Macmillan, 2007) 23; Katherine Stone, "Flexibilization, Globalization and Privatization: Three Challenges to Labour Rights in Our Time" (2006) 44:1 Osgoode Hall LJ 77. See Marie-Laure Morin, "Labour Law and New Forms of Corporate Organization” (2005) 144:1 Intl Lab Rev 5 at 7-13; Patrick Macklem, "Labour Law Beyond Borders" (2002) 5 J Intl Econ L 605 at 605-7; David Harvey, The Condition of Postmodernity: An Enquiry into the Origins of Cultural Change (Cambridge, Mass: Blackwell, 1989) at 159.

2. Kerry Rittich, "Transnationalizing the Values of American Labor Law" (2009) 57:3 Buff L Rev 803 at 808 .

3. See David Weil, The Fissured Workplace: Why Work Became So Bad for So Many and What Can Be Done to Improve It (Cambridge, Mass: Harvard University Press, 2014) at 185; Jake Rosenfeld, What Unions No Longer Do (Cambridge, Mass: Harvard University Press, 2014) at 18-19; Katherine VW Stone, From Widgets to Digits: Employment Regulation for the Changing Workplace (New York: Cambridge University Press, 2004) at 206-208.

4. For testaments to the importance of successor rights for the shape (and very possibility) of collective bargaining in the new economy, see Eric Tucker, "Great Expectations Defeated: The Trajectory of Collective Bargaining Regimes in Canada and the United States Post-NAFTA" (2004) 26:1 Comp Lab L \& Pol'y J 97 at 124-25; Philip M Schreiber, "Potential Liability of New Employers to Pre-Existing Collective Bargaining Agreements and Pre-Existing Unions: A Comparison of Labor Law Successorship Doctrines in the United States and Canada" (1992) 12:3 Nw J Intl L \& Bus 571; Joseph B Rose \& Gary N Chaison, "Unionism in Canada and the United States in the 21st Century: The Prospects for Revival" (2001) 56:1 Relations Industrielles 34 at 40-41. 
takes up part of a unionized business following privatization or reorganization. Labour adjudicators are often faced with complex economic arrangements and restructurings, to which they must apply broad criteria such as "continuity of the business" in order to make adjudicative choices (i.e., under what conditions to transfer certifications and collective agreements) that will determine the very structure of bargaining rights and in turn of the economy. European Union (EU) labour law deals with very similar problems through the so-called Acquired Rights Directive, ${ }^{5}$ which purports to maintain collective agreement and contractual rights in cases of business sales and reorganizations. ${ }^{6}$

This article presents an analysis of legal argument in classic Canadian successor rights cases dealing with the definition of the business changes that warrant the transfer of bargaining rights. It uses unconventional analytical methods to uncover patterns of "policy" argument that recur across various successor rights cases and could be used again in future cases dealing with different issues. In so doing, it maps the interconnectedness of present and future successorship cases with the hope of making this area of the law more comprehensible and easier to navigate. This is my sales pitch to labour law practitioners who are confronted with such cases. But this article is also intended as a broader intervention on legal thought in labour and employment law, as well as an example of a new approach to teaching and studying labour law doctrine.

Harry Arthurs, a leading Canadian labour law academic, has argued that the rise of the new economy described above has been accompanied by the rise of a "new legality," whereby labour law decision making has shifted from a model of ad hoc "problem solving" "in which results were measured by their positive industrial relations consequences to one in which they are measured by their conformity to the established jurisprudence." 8 He asserts that this new legality offers opportunities for employers to compromise the efficient pragmatism of specialized labour law decision making by rendering it adversarial and

5. Council Directive 77/187/EEC of 14 February 1977 on the approximation of the laws of the Member States relating to the safeguarding of employees' rights in the event of transfers of undertakings, businesses or parts of businesses, [1977] OJ, L61/26, now replaced by Directive 2001/23/EC of 12 March 2001 on the approximation of the laws of the Member States relating to the safeguarding of employees' rights in the event of transfers of undertakings, businesses or parts of undertakings or businesses, [2001] OJ, L82/16.

6. See John Armour \& Simon Deakin, "Insolvency and employment protection: the mixed effects of the Acquired Rights Directive" (2003) 22:4 Intl Rev L \& Econ 443 at 444, 451.

7. "The New Economy and the New Legality: Industrial Citizenship and the Future of Labour Arbitration" (1999) 7:1 Can Labour \& Employment LJ 46.

8. Ibid at 55. 
legalistic. ${ }^{9}$ Arthurs's argument is symptomatic of an intellectual trend I want to analyze and criticize.

Arthurs's depiction of traditional and established labour law reasoning is a remarkably persistent intellectual approach that lies at the heart of the post-war labour and employment legal regimes. This approach has an often-explicit legal theory, the central tenet of which is that labour and employment law is distinct from 'normal' legal reasoning in, say, private law in at least two ways: First, it is based on non-legal, pragmatic and ad-hoc responses by experts to social realities; and second, it is fundamentally based on purposive legal interpretation in light of the telos of achieving industrial peace, advancing the public interest, and redressing unequal bargaining power to maintain social stability. I will call this twofold legal theory the "old legality," by playful reference to Arthurs' terminology, although there are several other established terms I could have used. ${ }^{10}$ This approach or

9. Ibid at 57. While Arthurs was talking about labour arbitrators specifically (his article is based on remarks at an annual labour arbitration conference), he expressed his diagnosis in terms touching on labour law administrative decision-making more generally.

10. Some have called this paradigm "social legal thought," "social conceptualism," and "functionalism." See respectively Duncan Kennedy, "Three Globalizations of Law and Legal Thought: 1850-2000" in David M Trubek \& Alvaro Santos, eds, The New Law and Economic Development: A Critical Appraisal (New York: Cambridge University Press, 2006) 19 at 41 [Kennedy, "Three Globalizations"]; Karl E Klare, "Judicial Deradicalization of the Wagner Act and the Origins of Modern Legal Consciousness, 1937-1941" (1978) 62:3 Minn L Rev 265 at 278, 309 [Klare]; Kerry Rittich, "Functionalism and Formalism: Their Latest Incarnations in Contemporary Development and Governance Debates" (2005) 55:3 UTLJ 853. 
paradigm can be found in Canadian scholarship and treatises, ${ }^{11}$ case law $^{12}$ and

11. See George W Adams, Canadian Labour Law (Toronto: Thompson Reuters, 2016) at 4.30 (labour relations boards use their superior expertise and consider the "policy facts" in order to make rulings in light of the purpose of "intelligent regulation" of industrial relations); Wesley B Rayner, Canadian Collective Bargaining Law, 2d ed (Markham: Lexis Nexis Canada, 2007) at 84 (labour boards' legal reasoning as more "discretionary," "regulatory," and "general" than that of courts because of the purpose of setting "ground rules" for industrial relations); Donald D Carter et al, Labour Law in Canada, 5th ed (New York: Kluwer Law International, 2002) at 151 (describing the "web of rules" comprising "informal practices, customs and understandings" in the workplace as a "source" of labour law); Fernand Morin et al, Le droit de l'emploi au Québec, 4th ed (Montréal: Wilson \& Lafleur, 2010) at 134, 148, 166 (labour and employment law as "pragmatic," "teleological," distinct from the "strict and hard application of liberal law," and "incessantly evolving"); Michel Coutu and Georges Marceau, Droit administratif du travail: tribunaux et organismes spécialisés du domaine du travail (Montréal: Yvon Blais, 2007) at para 2 (labour law as an "autonomous social law" in which "collective rights" are paramount and as a "non-formal" and "flexible" form of administrative justice); Paul Weiler, "The Role of the Labour Arbitrator: Alternative Versions" (1969) 19:1 UTLJ 16 at 16-17 (labour arbitrators have "expertise and experience" in "peculiar 'non-legal' criteria, in particular the maintenance of peaceful, uninterrupted and fair industrial enterprise" and do legal interpretation based on "overriding labour relations goals...in the interests of the public"); David Beatty, "The Role of the Arbitrator: A Liberal Version" (1984) 34:2 UTLJ 136 at 148 (the role of the arbitrator is that of "discovering and 'working pure' th $[\mathrm{e}]$ industrial, common law of the shop" which includes "sound industrial relations standards"); Harry Arthurs, "Labour Law Without the State?” (1996) 46:1 UTLJ 1 at 3 (labour law is about the "indigenous production and enforcement of norms within the workplace," including customs and "scientific" management practices, as distinct from state law).

12. This intellectual framework has often been mobilized to justify curial deference to labour adjudicators including arbitrators and labour boards. MAHCP $v$ Nor-Man Regional Health Authority Inc, 2011 SCC 59, [2011] 3 SCR 616 (Fish J, establishing that labour arbitrators "are not legally bound to apply equitable and common law principles ... in the same manner as courts of law" because "theirs is a different mission, informed by the particular context of labour relations" at para 5. Arbitrators "may properly develop doctrines and fashion remedies appropriate in their field, drawing inspiration from general legal principles, the objectives and purposes of the statutory scheme, the principles of labour relations, the nature of the collective bargaining process, and the factual matrix of the grievances of which they are seized" at para 45. This was said to stem from the arbitrators' "distinctive role in fostering peace in industrial relations" at para 47); Toronto (City of) Board of Education v OSSTF, District 15, [1997] 1 SCR 487, 144 DLR (4th) 385 (Cory J, emphasizing the need for curial deference towards arbitrators, who are better equipped to render decisions that are "sensitive to the situation" of labour relations and to take account of the "basic requirement for peace in industrial relations" at paras 35-36); Ivanhoe Inc v UFCW, Local 500, 2001 SCC 47, [2001] 2 SCR 565 [Ivanhoe] (Arbour J, justifying deference to labour boards on successor rights issues on the basis that their members have "developed special expertise in this regard which is adapted to the specific context of labour relations and which is not shared by the courts," allowing them to further the purpose of "promot[ing] collective bargaining as a 
even legislation. ${ }^{13}$ It mostly relates to collective bargaining, the core of the post-war regime of labour and employment law. ${ }^{14}$ It is applied in equal measure to that regime's two central decision makers, grievance arbitrators and labour boards, and it is sometimes also put forward as a mode of legal reasoning that the judiciary should embrace and defer to when it rules on labour law matters. ${ }^{15}$ The old legality paradigm is often iterated by courts and scholars dealing with successor rights and the broad legal criteria that govern them. ${ }^{16}$ It seems clear that this intellectual pattern can be found at least in Canada, the United

better means of guaranteeing industrial peace and of establishing equitable relations between employer and employees" at para 26); United Food and Commercial Workers, Local $503 v$ Wal Mart Canada Corp, 2014 SCC 45, [2014] 2 SCR 323 (LeBel J, justifying curial deference to labour arbitrators on grievances for shop closures on the basis of their "expert knowledge and the fact that they are specialists in such matters" at para 88).

13. Pursuant to section 121 of Manitoba's Labour Relations Act, for example, arbitrators are free to consider "the real substance of the matter in dispute between the parties" and are "not bound by a strict legal interpretation of the matter in dispute." See Labour Relations Act, RSM 1987, c L10. A quasi-identical provision can be found at section 82(2) of the British Columbia Labour Relations Code. See Labour Relations Code, RSBC 1996, c 244. As for the purposive interpretation component of the old legality, the preamble of the Canada Labour Code once spoke of the "promotion of the common well-being through the encouragement of free collective bargaining." See Canada Labour Code, RSC 1970, c L-1, quoted in Health Services and Support-Facilities Subsector Bargaining Assn v British Columbia, 2007 SCC 27 at para 65, [2007] 2 SCR 391.

14. That said, some traces of it can be found regarding collective bargaining's more marginal cousin, individual employment standards statutes. See e.g. Ruth Sullivan, Sullivan on the Construction of Statutes, 5th ed (Markham, Ont: Lexis Nexis Canada, 2008) at 486-90 (establishing "social welfare legislation" as a distinct category of laws subject to broad purposive interpretation and not to the principles applicable to other types of legislation).

15. See supra note 12 .

16. See e.g. Adams, supra note 11; Ivanhoe, supra note 12; UES, local 298 v Bibeault, [1988] 2 SCR 1048, 13 ACWS (3d) 23 [Bibeault]. 
Kingdom, and the United States. ${ }^{17}$ It may even be found across the industrialized North Atlantic. ${ }^{18}$

In this article I propose a new approach to teaching and studying labour law doctrine that suggests that the old legality paradigm is not an accurate description of how labour and employment law works in practice. Taking a series of classic union successor rights decisions from Canada as a case study, I argue that labour law is made not through pragmatic, non-legal, and case-by-case purposive analysis, but rather proceeds as an endless chain of conventionally legal questions on which decision makers deploy policy argument to justify legal holdings. ${ }^{19}$ Thus, rather than the application of a single purpose to the factual matrix, the adjudicators and courts justify their holdings through contradictory policy arguments (including diverging purposes) that reveal deep normative conflict and contingency in the structure of labour law. To illustrate this argument, I use analytical methods created by American legal realists and critical legal studies. These include the technique of pairing contradictory arguments on a given question, and "nesting," whereby several distinct legal questions are reframed as an infinite chain of related, ever-narrower sub-questions on which

17. On the United States, see Samuel Estreicher \& Matthew T Bodie, Labour Law (St Paul, Minn: Foundation Press, 2016) at 56-57; Alvin L Goldman \& Roberto L Corrada, Labour Law in the USA, 3d ed (Alphen aan den Rijn, Netherlands: Kluwer Law International, 2011) at 78, 433; Michael C Harper, Samuel Estreicher \& Kati Griffith, Labor Law: Cases, Materials, and Problems, 8th ed (New York: Wolters Kluwer, 2015) at 649-50, 658; Roger I Abrams, Inside Arbitration: How an Arbitrator Decides Labor and Employment Cases (Arlington, VA: Bloomberg BNA, 2013) at 8, 10, 32; Frank Elkouri \& Edna Asper Elkouri, How Arbitration Works, 7th ed (Chicago: American Bar Association, 2012) at 1-1 to 1-3. On the United Kingdom, see Hugh Collins, KD Ewing \& Aileen McColgan, Labour Law (New York: Cambridge University Press, 2012) at 34; Anne CL Davies, Perspectives on Labour Law (New York: Cambridge University Press, 2004) at 3.

18. I am less confident about this. For analyses on France, see Antoine Mazeaud, Droit du travail, 2d ed (Paris: Monchrestien, 2000) at 14-15; Christophe Radé, Droit du travail et responsabilité civile (Paris: LGDJ, 1997) at 3-5. On Germany, see the materials cited in Roger Blanpain et al, The Global Workplace. International and Comparative Employment Law: Cases and Materials (New York: Cambridge University Press, 2007) at 409. For analyses positing my "old legality" as symptomatic of transnational trends in legal thought, including in labour law, see Justin Desautels-Stein, "Pragmatic Liberalism: The Outlook of the Dead" (2014) 55:4 BCL Rev 1041 at 1069; Kennedy, "Three Globalizations," supra note 10 at 41.

19. I will use the term "decision makers" to designate any and all bodies or persons adjudicating labour law matters, including labour boards, arbitrators, and courts. I will make it clear when I wish to refer only to administrative (as opposed to judicial) adjudicators, or only to a subset of those. 
the same arguments can be applied recurrently. ${ }^{20}$ Finally, I rely on theories of legal indeterminacy ${ }^{21}$ to emphasize what Max Weber called the "conflict of the gods": 22 intractable conflict between incommensurable values and norms, which manifest themselves here as policy arguments in favour of broader or narrower rules governing union successor rights.

There are several reasons why one would be interested in such an analysis. The first is analytical accuracy; I claim that my model of conflicting and incommensurable policy arguments is a better description of actual labour law reasoning than the old legality paradigm. Practitioners and legal theorists should be interested in this. The second impetus behind such a démarche is political. Seeing the post-war labour and employment law regime as animated by a coherent, purposive, and non-legal logic potentially has normative consequences for the scope of law reform projects we think are possible and desirable. The displacement of the post-war regime by a purported neoliberal deregulatory agenda may tempt labour lawyers to merely brandish the old legality flag of non-legal pragmatism, as opposed to advocating more profound legal changes both within and beyond the labour law regime in the direction of, say, radical equality, participation, and redistribution. In other words, as Karl Klare famously argued in his critique of the post-war labour model's "social conceptualism," the old legality might reinforce the status quo. ${ }^{23}$ Underlining the deep normative conflicts inside the pragmatic and purposive fortress might lead us to see the structure of the economy as much more open to contestation and redesigning. This article is thus based on the assumption that labour law doctrine matters a great deal politically. It is meant to counter a certain neglect of doctrine (and

20. See e.g. Karl Llewellyn, "Remarks on the Theory of Appellate Decision and the Rules or Canons about How Statutes Are to Be Construed" (1950) 3:3 Vand L Rev 395 [Llewellyn]; Duncan Kennedy, "Form and Substance in Private Law Adjudication" (1976) 89:8 Harv L Rev 1685 at 1723-24; Duncan Kennedy, "A Semiotics of Legal Argument" in Collected Courses of the Academy of European Law 3:2 (1994) 309 at 344, 346 [Kennedy, "Semiotics"]. See also Jack Balkin, “The Crystalline Structure of Legal Thought” (1986) 39:1 Rutgers L Rev 1 at 5 [Balkin].

21. See infra notes 133-135 and accompanying text.

22. "Science as a Vocation" in David Owen \& Tracy B. Strong, eds, The Vocation Lectures: "Science as a Vocation", "Politics as a Vocation" (Indianapolis: Hackett Publishing Company, 2004) at 27.

23. Klare, supra note 10. 
critical analysis thereof) in favour of institutional mechanisms and enforcement in contemporary labour law scholarship. ${ }^{24}$

The post-war purposes of redressing unequal bargaining power in order to attain stability and industrial peace have been criticized by sophisticated labour law theorists, who have proposed alternatives ranging from human rights ${ }^{25}$ (or capabilities theory ${ }^{26}$ ) to economic efficiency. ${ }^{27}$ But there has never been, to my knowledge, a sustained internal critique of the old legality's theory of

24. See e.g. Mark Anner, Jennifer Bair \& Jeremy Blasi, "Toward Joint Liability in Global Supply Chains: Addressing the Root Causes of Labor Violations in International Subcontracting Networks" (2013) 35:1 Comp Lab L \& Pol'y J 1; Cynthia Estlund, "Rebuilding the Law of the Workplace in an Era of Self-Regulation" in Brian Bercusson \& Cynthia Estlund, eds, Regulating Labour in the Wake of Globalisation: New Challenges, New Institutions (Portland: Hart Publishing, 2008) 89 at 112; Lance Compa, "From Chile to Vietnam: International Labour Law and Workers' Rights in International Trade” in Gráinne de Búrca, Claire Kilpatrick \& Joanne Scott, eds, Critical Legal Perspectives on Global Governance: Liber Amicorum David M Trubek (Portland: Hart Publishing 2013) 143 [de Búrca, Kilpatrick \& Scott]; Bob Hepple, Labour Laws and Global Trade (Portland: Hart Publishing, 2005) at 151-92; Alain Supiot, "Governing Work and Welfare in a Global Economy" in Jonathan Zeitlin \& David M Trubek, eds, Governing Work and Welfare in a New Economy: European and American Experiments (New York: Oxford University Press, 2003) 376 at 382-87; Virginia A Leary, "The Paradox of Workers' Rights as Human Rights" in Lance A Compa \& Stephen F Diamond, eds, Human Rights, Labour Rights, and International Trade (Philadelphia: University of Pennsylvania Press, 1996) 22 at 39-43.

25. See Bob Hepple, "Equality and Empowerment for Decent Work" (2001) 140:1 Int'l Lab Rev 5 at 9; Nicolas Valticos, "International Labour Standards and Human Rights: Approaching the Year 2000" (1998) 137:2 Int'l Lab Rev 135 at 138; Deirdre McCann, "Decent Working Hours as a Human Right: Intersections in the Regulation of Working Time" in Tonia Novitz \& Colin Fenwick, eds, Human Rights at Work: Perspectives on Law and Regulation (Portland: Hart Publishing, 2010) 509 at 514.

26. See Amartya Sen, "Work and Rights" (2000) 139:2 Int'l Lab Rev 82, republished as a "special supplement" in vol 152 (2013); Brian Langille, "Imagining Post Geneva Consensus Labour Law for Post Washington Consensus Development” (2010) 31:3 Comp Lab L \& Pol'y J 523 at 525; Tonia Novitz \& Colin Fenwick, Introduction: The Application of Human Rights Discourse to Labour Relations: Translation of Theory into Practice, in Novitz \& Fenwick, supra note 26 at 37; Jude Browne, Simon Deakin \& Frank Wilkinson, "Capabilities, Social Rights and European Market Integration" in Robert Salais \& Rovert De Villeneuve, eds, Europe and the Politics of Capabilities (New York: Cambridge University Press, 2004) 205.

27. See Alan Hyde, "The International Labor Organization in the Stag Hunt for Global Labor Rights" (2009) 3:2 L \& Ethics Human Rights 154 at 163; Christopher McCrudden \& Anne Davies, "A Perspective on Trade and Labour Rights" (2000) 3:1 J Int'l Econ L 43 at 51-52; Michael Trebilcock, "Trade Policy and Labour Standards: Objectives, Instruments and Institutions" in John Kirton \& Michael Trebilcock, eds, Hard Choices, Soft Law (Burlington, Vt: Ashgate, 2004) 170 at 173-74; David Charny, "Regulatory Competition and the Global Coordination of Labor Standards” (2000) 3:2 J Int'l Econ L 281 at 300. 
legal reasoning akin to that performed on deductive private law reasoning by anti-formalist scholars of all stripes. ${ }^{28}$ These include the American legal realists and their use of the category "policy" to emphasize the political contestability of nineteenth-century laissez-faire legal approaches. ${ }^{29}$ This is the kind of scholarly agenda I exemplify here using Canadian union successor rights adjudication as a case study. I chose successor rights adjudication because of its centrality to the old legality paradigm: Protection of bargaining rights is at the core of the perceived mandate of pragmatic and purposive labour decision makers, in this case labour boards. ${ }^{30} \mathrm{I}$ also chose successor rights because of their central political importance in the context of the disintegration of the North American labour law model in the face of changing business structures. As I will explain below, I could have illustrated my proposed approach using other topics of labour law. Confronted with a choice, I decided that union successor rights would be analytically and politically rewarding.

The article proceeds as follows. Parts I and II briefly summarize some of the classic successor rights cases from Ontario and Quebec whereby labour boards and courts have adopted and applied the test to determine whether there was a transfer of a business so as to trigger the application of successor rights provisions. I focus on the adoption of what the case law calls the "instrumental" approach to the question of how to define the business - that is, what degree of organizational continuity is required for bargaining rights to be transferred (a question that is also central to US union successorship law and EU acquired rights law). ${ }^{31}$ According to the instrumental approach, which replaced more union-friendly legal tests that transmitted bargaining rights when jobs were moved to a new employer, bargaining rights will not be transmitted merely when jobs are reassigned, but only when all key components of the business pass to the alleged successor employer. Four of the cases I analyze deal with subcontracting arrangements stemming from business reorganizations, and two deal with sales

28. The exception could be Klare, supra note 10.

29. See e.g. Wesley N Hohfeld, "Some Fundamental Legal Conceptions as Applied to Judicial Reasoning" (1913) 23:1 Yale LJ 16 at 36; Morris Cohen, "The Basis of Contract" (1933) 46:4 Harv L Rev 553 at 562; Robert Hale, "Bargaining, Duress, and Economic Liberty" (1943) 43:5 Colum L Rev 603 at 628.

30. Though this introduction refers to both grievance arbitrators and labour boards, my case study only deals with the latter as in Canada arbitrators do not deal with union successorship questions.

31. See Schreiber, supra note 4 at 576-80; Vivien Shrubsall, "Competitive Tendering, Out-sourcing and the Acquired Rights Directive" (1998) 61:1 Mod L Rev 85 at 89-91 [Shrubsall]. 
of assets following bankruptcy. Part III argues that, despite factual differences, these cases are best analyzed as interlocking legal questions answered by tribunals and courts as they work out the implications of the instrumental approach to the definition of the business. In this Part, I argue that decision makers have not merely applied the instrumental approach to new factual contexts but have had to make legal findings that were not dictated by that legal test. I read the cases from Ontario and Quebec together as a pyramid of (nested) sub-questions of law stemming from the adoption of the instrumental approach. I thereby underline the interconnectedness of holdings made under that test. This goes to the first trait of the old legality, i.e., the idea that labour law adjudication can be ad-hoc, non-legal, and context specific. Even though successor rights decisions often present themselves this way, I demonstrate that they are in fact interconnected legal holdings that build the cumulative framework applicable to successorship claims. In Part IV, I present the policy arguments that adjudicators have used to justify their decisions. I present summative tables of policy arguments drawn from all the cases covered in order to show that the legal questions from the cases are closely related. With a view to emphasizing that the arguments from the various cases can be intermingled, I present them in pairs, drawing on different cases (dealing with different questions) for each argument. The idea here is to demonstrate that the policies can be invoked under any of the nested sub-questions. In assembling this repertoire of contradictory policy arguments, I also address the second component of the old legality-i.e., the purported supremacy of purposive or teleological reasoning. What I mean to convey here is that purposive argument is seldom determinative, and that other policy arguments often supplement, counterbalance or set aside purposive arguments. I suggest that this reveals deep and incommensurable normative conflicts inside labour law.

I do not claim that my case study of a series of decisions is representative, either of labour law as a whole or even of all the successor rights cases out there. In fact, I do not think it is possible to assemble a set of cases from which one can generalize to a whole field of law on a strictly empirical basis. The analysis I propose here can thus be seen as a very preliminary illustration of a new kind of engagement with labour law doctrine, one that views it less as a purposive and pragmatic form of social engineering and more as a congealed political compromise that rests on unresolvable normative conflicts. It is meant to suggest that, by extending the model proposed here to other labour law questions and continuously bringing labour law's normative conflicts to the fore through teaching and research, labour law scholars can open up the status quo for 
normative contestation and gather momentum to redraw the legal system along more egalitarian lines.

\section{ONTARIO SUCCESSOR RIGHTS CASES: FROM METRO- PARKING TO AJAX}

In this part and the next, I summarize the cases I will use in my analysis of legal argument. These parts get into the lawyerly details of the cases and offer little theorizing. The reasons for this will become apparent as I flesh out my theoretical assumptions below. Suffice it to say for now that I think the best way to refute the old legality and to validate my model of intractable normative conflict is to be relentlessly concrete and to study actual argumentative practices as they play out in cases. This approach is based both on a practical and applied view of legal indeterminacy and on a taste for finding broader political significance in the technicalities of everyday legal reasoning. That is why this article takes the form of a concrete case study as opposed to a jurisprudential exposition. I hope the reader will bear with the detailed presentations in Parts I and II and I trust subsequent parts will make this somewhat dry read rewarding as they build an overarching critical analytical framework out of this primary material.

This part summarizes a few leading Ontario successor rights cases that I will use in my analysis of legal argument. These cases deal with the meaning of "sale of business" (defined very broadly as "includ[ing] leases, transfers and any other manner of disposition"), ${ }^{32}$ the prerequisite for a finding of successorship under the Ontario successor rights provision, section 69 of the Labour Relations Act..$^{33}$ I start with the foundational Metro-Parking case, in which the Ontario Labour Relations Board (OLRB) established the "instrumental approach" to the definition of business. ${ }^{34}$ According to that legal test, the transfer of a business

32. Labour Relations Act, 1995, SO 1995, c 1, Schedule A, s 69(1).

33. Section 69(2), the core provision, reads as follows:

Where an employer who is bound by or is a party to a collective agreement with a trade union or council of trade unions sells his, her or its business, the person to whom the business has been sold is, until the Board otherwise declares, bound by the collective agreement as if the person had been a party thereto and, where an employer sells his, her or its business while an application for certification or termination of bargaining rights to which the employer is a party is before the Board, the person to whom the business has been sold is, until the Board otherwise declares, the employer for the purposes of the application as if the person were named as the employer in the application (ibid).

34. Canadian Union of Public Employees v Metropolitan Parking Inc, [1980] 1 CLRBR 197, [1979] OLRB Rep 1193 [Metro-Parking]. 
must involve the organically central elements of the economic activity in question, and mere similarity of the work done by the previous business and the alleged successor cannot suffice. The adoption of the instrumental approach entailed rejection of a more expansive test, the "functional approach," according to which bargaining rights can be transferred when mere jobs (or "functions") are moved to another employer. Metro-Parking's instrumental approach is similar to the US Supreme Court's doctrine of "substantial continuity of identity in the business enterprise," ${ }^{\prime 3}$ applicable in American union successorship law, as well as to the approach adopted by the European Court of Justice (ECJ) under the EU Acquired Rights Directive. ${ }^{36}$ After dealing with Metro-Parking, I summarize the OLRB's subsequent Accomodex ${ }^{37}$ and $A j a x^{38}$ decisions, which applied the instrumental approach to other instances of business transfers. I discuss the cases in chronological order to give a sense of the way in which Ontario decision makers have elaborated the implications of the instrumental approach adopted in Metro-Parking, an approach they have never since repudiated. I then examine Quebec successor rights cases in Part II. I will build on these summaries in Parts III and IV as I lay out my combined study of legal argument that spans all the cases and intermingles the contradictory policy arguments that they contain.

Metro-Parking, a 1979 decision, involved two federal government subcontractors: Metropolitan Parking Inc (Metropolitan) and Toronto Auto Parks Ltd (TAP). TAP was engaged in managing and operating the parking installations at the Toronto Pearson airport as a subcontractor to the federal government, which owned the airport, the parking facilities, and the assets related to the parking business. ${ }^{39}$ The complainant union had obtained certification for

35. John Wiley \& Sons, Inc v Livingston, 376 US 543 at 551 (1964) [Wiley].

36. In the famous Süzen case, the ECJ held that there is no transfer of part of a business "if there is no concomitant transfer of significant tangible or intangible assets or the taking over by the new employer of a major part of the workforce, in terms of their numbers and skills, assigned by the predecessor to the performance of the contract." See Süzen $v$ Zehnacker Gebaudereinigung GmbH and Laefarth GmbH, C-13/95, [1997] ECR I-01259 at I-01263.

The ECJ further held that the business entity cannot be reduced to the activity entrusted to it but must "emerge[ ] from other factors, such as the entity's workforce, its management staff, the way in which its work is organised, its operating methods ... or the operational resources available to it" (ibid at I-01262).

37. Hotel Employees Restaurant Employees Union, Local 75 v Accomodex Franchise Management Inc, [1993] OLRB Rep 281, 19 CLRBR (2d) 1 [Accomodex].

38. National Automobile, Aerospace and Agricultural Implement Workers Union of Canada (CAW-Canada) and its Local $222 v$ Charterways Transportation Ltd, The Corporation of Ajax (Town of), [1994] OLRB Rep 1296, 24 CLRBR (2d) 280 [Ajax, OLRB].

39. Metro-Parking, supra note 34 at para 4. 
the employees of TAP, but had never held a certification binding the federal government. ${ }^{40}$ As TAP's contract with the government expired, Metropolitan was chosen to replace TAP as the manager of the parking facilities in the course of a competitive bidding process. Metropolitan recruited a "substantial number of TAP's bargaining unit employees" as well as much of TAP's management. ${ }^{41}$ However, there was "no corporate relationship" 42 between Metropolitan and TAP at any time.

Against this factual background, the OLRB held that there was no "sale of business" as per section 69 (then 55) of the Ontario Labour Relations Act. In essence, the OLRB held that "there must be more than the performance of like functions by another business entity" 43 for there to be a "sale" of business under the successor rights provision. As put by the OLRB:

There must be a transfer from the predecessor of the essential elements of the business as a block or as a "going concern." A business is not synonymous with its customers or the work it performs or its employees. Rather, it is the economic organization which is used to attract customers or perform the work. ${ }^{44}$

This has been referred to as the instrumental definition of the business, as opposed to a "functional" definition which hinges on the similarity of the employees' functions or work. ${ }^{45}$ It will be apparent that the functional approach, which Metro-Parking rejected, is more pro-union than the instrumental approach that the case adopted, as it allows for more transfers of bargaining rights. Metro-Parking also introduced a second requirement that became central to ulterior case law: that of a "sale" (in the sense of an actual transfer), later referred to as the need for a "nexus" between the alleged successor and transferor. This is equivalent to the European Court of Justice's requirement of a "contractual link" for transfer of acquired rights under EU labour law. ${ }^{46}$ By rejecting the argument that the loss of TAP's contract and the simultaneous hiring of some of TAP's employees constituted a "sale," 47 the OLRB made a very influential finding.

40. Ibid at para 2. This will become very important for subsequent discussion of the application of the test devised in Metro-Parking.

41. Ibid at para 14-15.

42. Ibid at para 3 .

43. Ibid at para 44 .

44. Ibid.

45. See e.g. Ajax (Town) v CAW, Local 222, 2000 SCC 23, [2000] 1 SCR 538, at para 9 [Ajax]; Bibeault, supra note 16 at para 75.

46. Shrubsall, supra note 31 at 86.

47. Metro-Parking, supra note 34 at para 45. 
In 1993, somefourteen years after Metro-Parking, the Accomodexcase presented an occasion for the OLRB to clarify some implications of the instrumental approach. The question the OLRB faced in Accomodex was whether a transaction involving only a transfer of assets, with no significant transfer of employees (but with similarity of functions), should automatically be considered insufficient as per the instrumental approach to successor rights. A second, related question was whether a hiatus between the operations of alleged successive employers is determinative and must lead to the rejection of a successorship claim.

Accomodex involved Skyline Triumph Hotel (Triumph), which had closed because of financial difficulties. ${ }^{48}$ The employees of the hotel had been represented by a labour union. Eighteen months after the closing, Kelloryn Consulting Inc (Kelloryn) acquired "the lands, buildings and virtually all of the other tangible assets formerly used by the Triumph in its hotel operation." ${ }^{49}$ The OLRB found that there was no significant continuity in the workforce, since only ten out of the 150 ex-employees of Triumph had been hired to work in the new hotel. ${ }^{50}$ The OLRB, however, did note that the functions, that is, the work performed by the new employees, were essentially the same as those performed by the former employees of Triumph. ${ }^{51}$ In this context, the OLRB answered two related questions of law that were potentially determinative: first, whether a transfer of mere assets (presumably combined with similarity of functions as in Accomodex) can, as a matter of law, lead to a finding of successorship; and second, whether a hiatus between the alleged successive businesses necessarily impedes a finding of successorship. Before answering these questions, the OLRB reiterated that the applicable test was the instrumental definition of the business, i.e., a view of the business as an integrated whole that goes beyond mere similarity of work. ${ }^{52}$ The OLRB also reiterated its finding in Gordons Markets that a change of employees is not determinative of the successor rights claim. ${ }^{53}$ Having made these remarks, the OLRB found as follows:

48. Accomodex, supra note 37 at para 15 .

49. Ibid at para 18 .

50. Ibid at para 37.

51. Ibid at para 40.

52. Ibid at paras 54-55.

53. Ibid at para 61, citing Retail Clerks Union Local $206 v$ Gordons Markets a Division of Zehrmart Ltd, [1978] OLRB Rep 630, [1978] 2 Can LRBR 460. The Gordons Markets case involved a grocery store going out of business and a subsequent business taking over its lease to open a new grocery store on the same premises, without purchasing any inventories or equipment and, importantly, without hiring former employees. 
$[\mathrm{W}] \mathrm{e}$ do not think that hiatus is conclusive where, as here, the asset configuration has remained substantially intact and continues (albeit with renovations) at the core of the "new" business organization. Our decision has the effect of affixing bargaining rights to an asset configuration, but in all the circumstances, we do not think that this is inappropriate when this "part" of the predecessor's organization is so integral or essential to its operating capacity. ${ }^{54}$

Thus, a hiatus will not be determinative and a transfer of assets may suffice, if such assets are fundamental to the business. This adds considerable precision to the legal framing of the instrumental approach in Ontario as to what can and cannot suffice under successor rights provisions. After answering these legal questions, the Board turned to the case at hand and found successorship, in part because on the facts of the case the assets (and their location) were a fundamental component of the business, as they had "a relationship with its local market." 55

The OLRB dealt with another high profile successorship question in the 1994 case of Ajax. $^{56}$ In that case, the Town of Ajax was faced with a successor rights claim related to employees it had recently hired in an effort to reassume control over the operation of its transit system. The complainant union had obtained certification for the employees of Charterways, a private contractor that had operated the Ajax public transit system from its creation. The Town of Ajax had always been the owner of the assets related to the transit system (buses, buildings, payment systems, et cetera), while Charterways "provided and coordinated a complement of trained drivers to operate the buses, and a group of mechanics and cleaners to maintain and repair the fleet." ${ }^{57}$ When Charterways's contract with the Town of Ajax expired in 1992, however, the Town decided to assume operation of the transit system. Charterways thus terminated the employees formerly involved in the operation of the transit system. The Town of Ajax then launched a recruitment campaign, as a result of which a "substantial majority" 58 of its new employees were former employees of Charterways. The OLRB ruled that Ajax was the successor employer to Charterways, relying on some policy arguments that I will outline below, as well as some key factual findings. The OLRB found that Charterways's former business "was not the provision or operation of a bus service," but rather "consisted primarily of the provision of a skilled work force to the Town." ${ }^{59}$ As a consequence, the OLRB held that the

54. Ibid at para 81 .

55. Ibid at para 78 .

56. Ajax, OLRB, supra note 38 .

57. Ibid at para 14.

58. Ibid at para 24 .

59. Ibid at para 40. 
workforce taken back by Ajax was Charterways's "most valuable asset," ${ }^{60}$ one that was "essential to the continued operation of the transit system." ${ }^{1}$ The OLRB also emphasized that Ajax actively solicited the employees' applications, and that as a consequence it "took back more than it initially contracted out." ${ }^{2}$

The OLRB's decision was quashed by the Ontario Divisional Court on judicial review, mainly on the basis that "there was no 'nexus', 'legal act' or 'legal relation" "63 between Ajax and Charterways. In other words, unilateral hiring of another business's employees is not enough. On appeal, the Ontario Court of Appeal purported to restore the OLRB's ruling on this point. The Court of Appeal found that the "nexus between Charterways and the Town is the commercial history without which the Town's acquisition of the work force would not have occurred." ${ }^{64}$ The Court of Appeal also agreed with the OLRB that a "business" had indeed been transferred through the hiring of the employees. ${ }^{65}$ The Supreme Court of Canada upheld the Court of Appeal's decision, noting that the "historical and functional connection between Charterways and the Town of Ajax" ${ }^{16}$ was not an unreasonable basis for the OLRB's finding of successorship.

\section{QUEBEC SUCCESSOR RIGHTS CASES: FROM BIBEAULT TO IVANHOE}

The two Quebec cases I analyze follow a similar pattern to those in Ontario in that they first forcefully affirmed an "organic" or instrumental approach to successor rights (in Bibeault) ${ }^{67}$ and then added some precisions (in Ivanhoe) ${ }^{68}$ as to what that test entails. In this part I briefly summarize the two cases before assessing the conceptual relationship between them and the Ontario cases in part III.

Bibeault involved three subcontractors performing janitorial work for a school board. Two of these subcontractors, BDM and Netco, originally had contracts

60. Ibid at para 41 .

61. Ibid at para 42 .

62. Ibid.

63. CAW, Local $222 v$ Charterways Transportation Ltd, 95 CLLC 210-040 at para 40, 84 OAC 281 (Ont Gen Div) [Ajax, Div Ct].

64. Ajax (Town of) v National Automobile, Aerospace and Agricultural Implement Workers Union of Canada (1998), 41 OR (3d) 426, [1998] 166 DLR (4th) 516 (CA) at para 25 [Ajax, ONCA].

65. Ibid at paras 26-27.

66. Ajax, supra note 45 at para 2.

67. Bibeault, supra note 16.

68. Ivanhoe, supra note 12. 
with the school board, and their employees were under a union certification. Notably, the school board was never the employer of the janitors, who were from the start recruited by the subcontractors. ${ }^{69}$ After the subcontractors' employees went on strike, the school board terminated the subcontracts and retained the services of a new subcontractor, Services Ménagers Roy Ltée (Roy). The union initiated proceedings under the Quebec successor rights provision (section 45 of the Quebec Labour Code) to be declared the bargaining agent for the Roy employees. ${ }^{70}$

Justice Beetz, writing for a unanimous Supreme Court, put an end to a division in Quebec labour law between advocates of "functional" and "organic" (instrumental) definitions of the "undertaking" (the business). ${ }^{71}$ The Court unequivocally rejected the functional definition, stressing that two entities cannot be successors "solely because each of them hires employees engaged in similar activities." ${ }^{\prime 2}$ Instead, Justice Beetz adopted the organic definition put forward by Justice Lesage of the Quebec Labour Court, a definition that is strikingly similar to Metro-Parking's instrumental approach (and to the ECJ's approach in the aforementioned Süzen case): ${ }^{73}$

It is thus incorrect to treat the undertaking and the positions or functions listed in the certificate of certification as equivalent. ... Instead of being reduced to a list of duties or functions, the undertaking covers all the means available to an employer to attain his objective. ${ }^{74}$

69. Bibeault, supra note 16 at para 5 .

70. CQLR c C-27, ss 45. The provisions read as follows:

The alienation or operation by another in whole or in part of an undertaking shall not invalidate any certification granted under this Code, any collective agreement or any proceeding for the securing of certification or for the making or carrying out of a collective agreement.

The new employer, notwithstanding the division, amalgamation or changed legal structure of the undertaking, shall be bound by the certification or collective agreement as if he were named therein and shall become ipso facto a party to any proceeding relating thereto, in the place and stead of the former employer.

71. Ibid. I am using the words "business" and "sale" instead of "undertaking" and "alienation or operation by another," used in the English version of section 45 of the Quebec Labour Code. I do so because the latter expressions strike me as clumsy translations of entreprise and aliénation, two French words roughly equivalent to "business" and "sale."

72. Bibeault, supra note 16 at para 219.

73. Ibid at para 67; supra note 36 .

74. Bibeault, supra note 16 at paras 173-74. 
Justice Beetz also held that one of the corollaries of the organic approach is the need for a direct "legal relation" between successive employers. ${ }^{75}$ This is roughly equivalent to the "nexus" in Ontario law and the ECJ's "contractual link" requirement. ${ }^{76}$ This essentially doomed the union's claim, which relied in part on the idea that the relationship between Roy and the school board created a legal relation with the previous subcontractors. Since the school board had never been the employer of the janitors, it did not transfer anything to Roy. Moreover, the three subcontractors had never planned any transfer of business; the replacement of BDM and Netco by Roy was caused by competition for contracts alone. ${ }^{77}$ Therefore, the Court dismissed the union's claim and the new janitors were not unionized.

In 2001, the Supreme Court decided an appeal relating to the framework laid out in Bibeault. Ivanhoe Inc owned and managed a shopping center. It originally employed the mall's janitors itself ${ }^{78}$ and later subcontracted the janitorial services to Moderne, which hired the same employees. ${ }^{79}$ Ivanhoe called for bids at the end of its contract with Moderne. Moderne did not submit a bid. Ivanhoe entered into contracts with four companies to replace Moderne's janitorial services. Moderne's workers from the Ivanhoe mall were all terminated and none of them were hired by the new contractors. The work performed by the alleged successors was identical to that previously performed by Moderne. ${ }^{80}$ The union that had represented the janitors employed first by Ivanhoe and then by Moderne filed a claim under the Quebec successor rights provision to be declared the bargaining agent of the new janitors working on the premises of the shopping center.

In Ivanhoe, the Supreme Court validated two theories or doctrines relied upon by the Quebec Labour Court: the "theory of retrocession" and what I will call the doctrine of the right to operate. These two doctrines correspond respectively to the two requirements of successor rights outlined in Bibeault (and Metro-Parking): the need for a "legal relation" (or nexus) and the need for a transfer of a business (defined in an organic or instrumental manner). On the first element, the Court accepted as reasonable the theory of retrocession, which had been elaborated by the Quebec Labour Court long before Bibeault. ${ }^{81}$ According to that theory, successor rights provisions do not apply when the work

75. Ibid at paras 185, 205.

76. Shrubsall, supra note 31 .

77. Bibeault, supra note 16 at paras 216-18.

78. Ivanhoe, supra note 12 at para 3.

79. Ibid.

80. Ibid at para 6 .

81. Ibid at para 83 . 
of a unionized subcontractor is transferred to a second subcontractor (as was the case in Bibeault and, incidentally, in Metro-Parking). The theory of retrocession, however, allows a finding of successorship where the entity that is subcontracting the work was originally covered by a certification (as was the case in Ivanhoe). ${ }^{82}$ Provided that sufficiently important elements of the business are transferred, the subcontracting employer is held to have passed on the business to the first subcontractor, taken it back and then passed it on again ("retroceded" it) to the second subcontractor. ${ }^{83}$ On the second element, the Court held that a "right to operate," defined as the "right to perform specific duties at a specific location for a specific purpose," ${ }^{84}$ could suffice to trigger successor rights provisions if it is combined with the "transfer of functions," ${ }^{85}$ meaning a transfer of jobs, not necessarily of employees. The Court held that this definition was consistent with the organic approach adopted in Bibeault. It confirmed the issuance of an order transferring the union certification to the four subsequent subcontractors. ${ }^{86}$

82. Ibid at para 3 .

83. Ibid.

84. Ibid at para 51.

85. Ibid at para 72 .

86. The Quebec legislature amended the successor rights provisions as a direct reaction to the Supreme Court's ruling in Ivanhoe, expressly repudiating the Court's decision by adding the words "in addition to functions or the right to operate." The new art 45 of the Labour Code reads as follows:

The second paragraph [the successor rights provision] does not apply in the case of the transfer of part of the operation of an undertaking where such transfer does not entail the transfer to the transferee, in addition to functions or the right to operate, of most of the elements that characterize the part of the undertaking involved. [emphasis added] (RSQ 2003, c C-27, art 45).

For a while it was not clear how this provision was to be interpreted by labour boards and courts. If the provision is taken at face value, it might forbid any finding of successorship in cases where a subcontractor takes up a new contract without more. The Quebec labour board has adopted this interpretation, which essentially rules out the Ivanhoe holding that bargaining rights can be transferred when a "right to operate" is transferred along with jobs only. See Union des employés \& employées de service, local 800 c École Maïmonide - CPE, 2007 QCCRT 69, DTE 2008T-478 at para 20. Interestingly, however, in a widely-read Quebec Bar casebook prepared by several partners of the (now defunct) management-side firm Heenan Blaikie LLP, it was still recently argued that the provision could receive another, "restrictive interpretation," "requiring the transfer of characteristic elements other than work, if there are any." See Geneviève Beaudin et al, Droit du travail (Cowansville, QC: Thomson Reuters, 2011) at 160 [emphasis added, translated by the author]. This might provide the seeds for another high-profile successorship battle by opening the door to an application of the Ivanhoe ruling in some circumstances where the work can be said to be the only element characterizing the business. 


\section{READING THE CASES TOGETHER: QUESTIONS OF LAW IN PYRAMIDAL INTERCONNECTION}

This part reads the cases summarized above together, setting the table for a broader analysis of legal argument across all cases. I argue that the instrumental definition of the business, adopted in both provinces, does not eliminate further disagreement as to the adoption of certain rules to specify the requirements of the test applicable to successor rights. I also relate the different issues posed by the successor rights cases in order to describe how the instrumental approach has developed since Metro-Parking and Bibeault. This will allow me to present, in Part IV, an overarching analysis of all the policy arguments raised in support of broader or narrower successorship rules, thereby illustrating my proposed approach of eschewing the old legality and emphasizing the unresolved legal conflicts that run across a given series of labour law decisions.

As we have seen, Ontario and Quebec both have foundational cases in which there was consensus in favour of an instrumental or organic approach to successor rights. However, both provinces have seen high profile labour disputes over what exactly the instrumental approach entails in specific cases (just as the ECJ has in the context of its own instrumental approach to business transfers under the European Acquired Rights Directive) ${ }^{87}$ I now make two claims about this succession of legal disputes: first, that the instrumental approach does not in itself provide an answer to subsequent disputes, and second, that these disputes are best described as questions of law whereby a rule is added to the instrumental approach, as opposed to a mere "application" of that approach to the facts of each case.

The first claim is that while the adoption of the instrumental approach was a turning point in the case law, it did not provide enough guidance to settle subsequent disputes. Thus, litigants can disagree as to whether, for example, a mere sale of assets should be considered a priori sufficient or not, while wholly agreeing that the instrumental approach to successor rights is the test that applies. The resolution of this disagreement is not obvious, as the instrumental approach is defined negatively: Successorship findings cannot be based merely on similarity of functions. Beyond that, the adjudicator must look for a transfer of the "essential elements of the business as a block or as a 'going concern." 88 Given the generality of this test, it is to be expected that subsequent questions would

87. See Gavin Barrett, "Deploying the Classic 'Community Method' in the Social Policy Field: The Example of the Acquired Rights Directive” (2009) 15:2 Eur LJ 198 at 205.

88. Metro-Parking, supra note 34 at para 44. 
be raised as to whether certain specific factors should be a priori insufficient (as the similarity of functions was). Figure 1 illustrates the relationship between the cases summarized above:

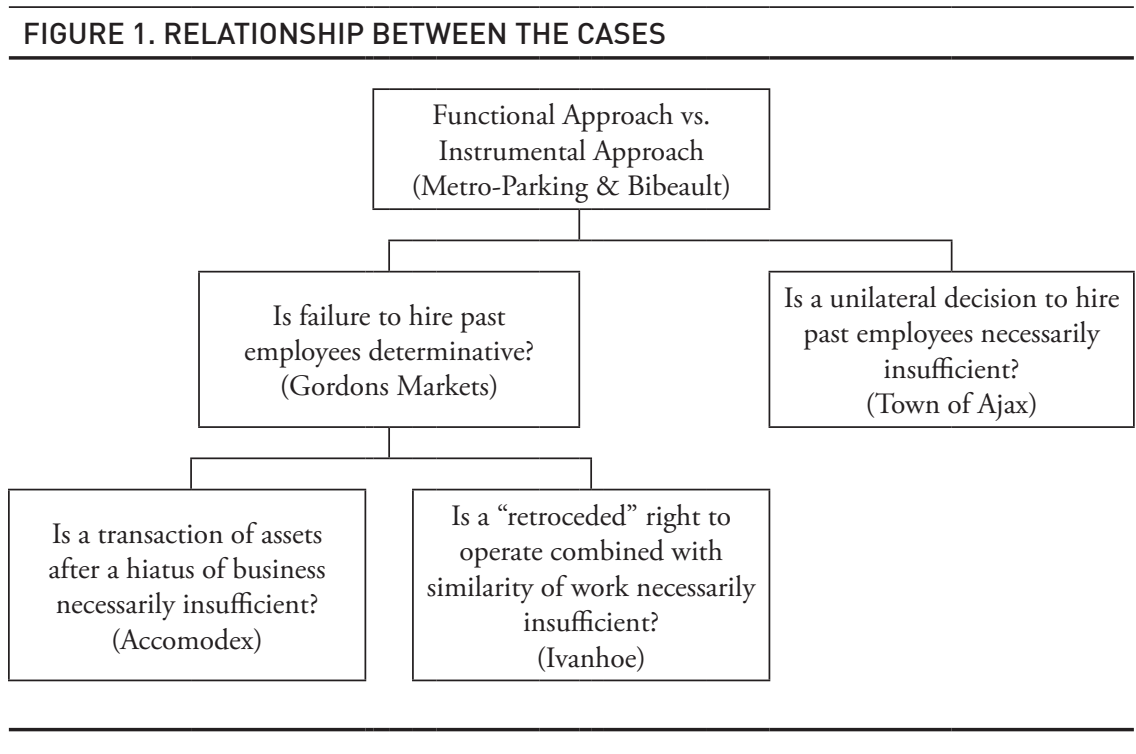

As can be seen from Figure 1, the cases all dealt with the question of whether or not a certain transferred element can suffice at all for a finding of successorship (as was also the case in the ECJ cases dealing with the Acquired Rights Directive). ${ }^{89}$ For instance, the Gordons Markets case answered the question of whether the failure to hire employees from the alleged predecessor always dooms a successor rights claim. ${ }^{90}$ In that case the court held that failure to hire is not determinative. Once that question was answered, it was open to unions to make claims in cases where some other element of the business was transferred, but not the employees. In those cases as well, the employer could raise the question of whether the particular elements should systematically be considered insufficient. For instance, in Accomodex it was argued that a mere transfer of assets, combined with a hiatus between the operation of the two businesses, should be held insufficient. Likewise, in Ivanhoe the question was whether a "right to operate" (defined in relation to a specific location and specific tasks) that is "retroceded" by a subcontracting

89. Shrubsall, supra note 31 at 89-91.

90. Supra note 53. 
employer originally bound by the certification can be sufficient as per the instrumental approach, even where the employees are not transferred. Finally, in Ajax the issue was whether a unilateral decision to hire employees can ever be a sufficient "nexus," and whether employees alone can ever be sufficiently important elements of the business to warrant a finding of successorship. In deciding these matters, adjudicators cannot merely "apply" the instrumental approach, as the questions go beyond what was settled in Metro-Parking and Bibeault, i.e., the mere rejection of a test that hinges on similarity of functions. This is not to say that these legal issues are wholly independent of the initial choice of an instrumental approach. In Part IV I will outline how policy arguments invoked in favour of and against the instrumental approach have been subsequently raised in favour of various rules addressing what the instrumental approach entails (this is what I will call "nesting"). Nevertheless, none of the cases in my diagram turned only on how to "apply" the instrumental approach to the facts; instead, each of them saw the adjudicator weigh general policy arguments that resonate with the other cases involving successor rights and rule more definitively on the sufficiency of a given factual element.

My second claim is that the cases in Figure 1 all involved choices that are best characterized as questions of law, not as rule application (or "questions of mixed law and fact").9 Indeed, these cases all turned on the question of whether certain specific characteristics can suffice to constitute a sale of business as per the instrumental approach. Although the adjudicators had to apply whatever test they devised to the facts of the case at hand, the disagreement was over the definition of the legal test and specifically whether that test should a priori exclude some elements as insufficient (as was done with mere continuity of work when the instrumental approach was adopted). As put by Justice Bastarache in his dissent in Ajax, one of the questions in that case was whether "commercial history on its own can constitute a sufficient nexus." ${ }^{\text {92 }}$ Likewise, Accomodex dealt with the claim that a hiatus is always determinative. The same goes for the other cases. In that sense, even after Ontario and Quebec courts definitively chose the instrumental approach (in Metro-Parking and Bibeault, respectively), questions remained unanswered as to what this entailed as a matter of law. Seeing those cases as involving questions of law is an important step towards breaking with the old legality's view of labour adjudication as the ad-hoc and contextual application

91. Canada (Director of Investigation and Research) v Southam Inc, [1997] 1 SCR 748 at para 35, 144 DLR (4th), Iacobucci J.

92. Ajax, supra note 45 at para 9 [emphasis added]. 
of broad legal criteria. On my view, labour disputes are much more interrelated, and it is possible to map common structures of argument across series of cases.

\section{BEYOND PURPOSE AND PRAGMATISM: MAPPING THE POLICY LANDSCAPE}

In this part, I bring the various successor rights cases together to blend the policy arguments they contain. But before I outline these arguments, I explain what I mean by "policy." Policy is a word long used in American private law discourse. The following definition is largely inspired by the literature on policy argument in private law, which I propose to adapt to the labour law context. ${ }^{93} \mathrm{My}$ discussion relies on (one might say anthropological) observations of a common practice, not on any theory of legal interpretation of my own. I take policy arguments to be arguments about the societal consequences of a given legal rule, as opposed to arguments based on deductive reasoning (say, from the concept of rights) or purposive interpretation. Thus, the classic example of policy arguments is what Jack Balkin calls social utility arguments, which "concern the practical consequences of a particular rule choice" and "are often expressed in terms of broad social policies that their advocates believe the law should foster." ${ }^{\text {" }}$ There are also administrability arguments, which concern the framing of legal norms either as rigid rules or as open-ended standards, each with its own purported virtues and vices (e.g., certainty versus flexibility). ${ }^{95}$ Arguments based on legal expectations (and the extent to which a given rule responds to them) are also part of what I mean by policy. ${ }^{96}$ The foregoing are examples of what you might call consequentialist policy arguments. But policy is quite a capacious rhetorical repertoire, and other kinds of arguments come into play. Indeed, rights can sometimes intervene not as deductive arguments but as policy considerations to be balanced against other desiderata. ${ }^{97}$ Finally, institutional competence

93. See all references in supra note 27.

94. Balkin, supra note 20 at 32.

95. See Pierre Schlag, "Rules and Standards" (1985) 33:2 UCLA L Rev 379 at 383.

96. On the role of expectations argument in private law, see Melvin Aron Eisenberg, The Nature of the Common Law (Cambridge, Mass: Harvard University Press, 1988) at 37-42; Kennedy, "Semiotics," supra note 20 at 328, 332.

97. For scholarly takes treating "rights" as just one type of policy to be balanced against other utilitarian considerations, see Donald Reagan, "Glosses on Dworkin: Rights, Principles, and Policies" (1978) 76:8 Mich L Rev 1213 at 1232; Kent Greenawalt, "Policy, Rights and Judicial Decision" (1977) 11:5 Ga L Rev 991 at 1004; David Lyons, "Justifications and Judicial Responsibility" (1984) 72:2 Calif L Rev 178 at 188-89. 
arguments concerning the separation of powers between courts and legislatures (say, the extent to which a given rule requires courts to enter legislative terrain) are sometimes invoked in the same fashion. ${ }^{98}$

Of course, purposive arguments are still recurrent in labour law and appear alongside policy arguments. It is just that they are only rarely (if ever) conclusive. Indeed, there can be significant disagreement as to what rules to deduce from the purpose. Thus, rather than being determinative, purposive arguments are often balanced against competing considerations, or even against competing interpretations of the purpose. For instance, it often does not amount to much to argue that a given successor rights rule gives effect to the purpose of protecting bargaining rights, because the opponent can answer that the legal rule amounts to extending, not protecting, existing bargaining rights. In other words, purposive argument itself becomes a terrain of struggle, which can open the door to other conflicting policy considerations.

I now turn to the arguments relied on by the decision makers in the cases. I regroup them according to whether they justify "broader" or "narrower" successor rights rules and present them in Tables 1 and 2 . The instrumental approach itself is an example of a narrower rule in that it is more restrictive than the alternative functional approach, which is based on the sufficiency of similarity of jobs. The proposition that unilateral hiring of employees can be sufficient and the theory of retrocession are examples of broader rules, as they lead to more transfers of bargaining rights than their alternatives, i.e., that unilateral hiring and retroceded contracts are always insufficient. My basic idea is that while each of the arguments was formulated with respect to the particular question at hand, it can also be invoked to support other legal rules that are on the same side (i.e., favouring narrower or broader interpretations). This means that, for example, arguments invoked in favour of a rule that unilateral hiring never creates a sufficient nexus could be invoked against the theory of retrocession. This is an application of the idea of "nesting." Duncan Kennedy describes this phenomenon, taking the tort law example of deciding whether to allow a defence of mistake in certain circumstances and, supposing such a defence is allowed, subsequently deciding whether to apply an objective standard to the mistake:

98. This theme of argument was the historical product of the influence of "process" theories of law like those of Lon Fuller, Henry Hart, and Albert Sacks, who were preoccupied with finding the most appropriate forum for a given legal decision. See Gary Peller, "Neutral Principles in the 1950's" (1988) 21:4 U Mich JL Ref 561 at 566-72. For an application of the institutional competence policy theme in private law, see Melvin Aron Eisenberg, "The Responsive Model of Contract Law" (1984) 36:5 Stan L Rev 1107 at 1117-27. 
'Nesting' is my name for the reproduction, within a doctrinal solution to a problem, of the policy conflict the solution was supposed to settle. [...] 'Nesting' is the reappearance of the inventory when we have to resolve gaps, conflicts or ambiguities that emerge when we try to put our initial solution to a doctrinal problem into practice. In this case, we first deploy the pro and con argument-bites in deciding whether or not to permit a defence of mistake. We then redeploy them in order to decide whether to require that the mistake be made reasonable. ${ }^{99}$

The idea is that arguments can be transferred from one question to the next indefinitely. This does not mean that differences, both geographic and temporal, do not matter when analyzing cases from different jurisdictions and periods. For example, there might be differences in the applicable legislative wording, both over time and between jurisdictions, that complicate the kind of analysis I propose. But this is not a problem for the six cases I analyze here. The Ontario and Quebec legislation, for all intents and purposes, did not change throughout the time periods covered by my cases. ${ }^{100}$ That said, there are some slight differences between Ontario and Quebec successor rights law, including the fact that the Quebec provision extends not only to sales of business but also to cases where a business is "operated by another." 101 This difference is of little consequence, however, as all my cases deal with fact patterns that fall under both provisions. ${ }^{102}$ But even if there were such differences between the cases, they would not invalidate or prevent the kind of structural analysis of legal argument I am proposing here. All the questions I map in Figure 1 had to be settled judicially

99. Kennedy, "Semiotics," supra note 20 at 344, 346.

100. This can be confirmed by a quick glance at the provisions transcribed in the decisions I analyze. In the case of Ontario, my four cases were not affected by the 1993 amendments to the Labour Relations Act that provided for successor rights protection for retendered service contracts nor by the 1995 amendments that repealed those provisions and took Crown employees outside the scope of successor rights provisions to facilitate privatization. For an overview of those contradictory amendments, see Harish C Jain \& S Muthu, "Ontario Labour Law Reforms: A Comparative Study of Bill 40 and Bill 7” (1996) 4 CLELJ 311 at 323-25. The reason the Ontario cases are not affected is that the only case potentially subject to those provisions, Ajax, involved neither service contracts nor Crown employees. In the case of Quebec, though the cases analyzed here are not touched by any legislative amendment, the successor rights provision was amended shortly after the Supreme Court rendered its Ivanhoe ruling. For thoughts on how the jurisprudential debates I analyze here could be extended into this new legislative context, see supra note 87.

101. See supra note 70.

102. For an example of a fact pattern where this distinction would make a difference, we can think of a receiver operating a business as part of a receivership regime, which would likely be captured by the Quebec but not the Ontario successorship provision. See, Adams, supra note 11 at para 8.54, giving the example of St-Louis Redding Co. (Re) (1982), 42 CBR (N.S.) 75 (Qc Lab Com'r). 
and were thus not conclusively answered by the legislative wording in force (nor, I would add, by the applicable precedents). My point is precisely that even for cases dealing with distinct questions in different legislative and jurisprudential contexts (and in two provinces), it is still possible to extract a common pattern of policy arguments that are interchangeable across all the different questions (provided the questions are sufficiently related to be "nested"). It is this common structure of argument, rather than details of the jurisprudential and legislative background, that I propose be relentlessly tracked both to get a better sense of possible argumentative strategies and to map the unresolved normative conflicts at the heart of the labour law regime.

I have grouped the arguments in fourteen pairs: in seven pairs, the initiative comes from the party advocating broader successorship rules (the union); in the other seven the initiative comes from the party advocating narrower rules (the employer).$^{103}$ However, my configuration is not the only one possible; far from it. Many arguments could respond to more than one opposing claim. Moreover, these arguments could be persuasive on their own. Thus, my list is better seen as a group of 28 individual policy arguments than as a list of fixed pairs.

\section{TABLE 1: UNION-INITIATED ARGUMENT PAIRS}

Arguments for a Broader Interpretation of Successor Rights Provisions

1a. The broader rule is appropriate because it gives effect to the remedial purpose of successor rights provisions. ${ }^{104}$
Arguments for a Narrower Interpretation of Successor Rights Provisions

$1 b$. The broader rule is inappropriate because it defeats the legislative intent by expanding instead of merely protecting bargaining rights. ${ }^{105}$

103. By “initiative," I do not refer to who initiates the procedures. For obvious reasons, unions are almost always the ones bringing successorship claims following an employer's business decision. Rather, I refer to a chronological order, i.e., who voices the first argument and who responds. This is a heuristic move meant to better illustrate the fact that the second argument of a pair is often a response to the first one.

104. Metro-Parking, supra note 34 at para 27; Ivanhoe, supra note 12 at para 94, quoting Ajax, $\mathrm{O} N C A$, supra note 64 at para 24.

105. Accomodex, supra note 37 at para 64. 
2a. The narrower rule marking certain elements as fatal to a successorship claim amounts to reading in restrictions on the scope of successor rights provisions and subverting legislative intent. ${ }^{106}$

3a. The broader rule responds to employees' legitimate expectation that their bargaining rights will not be nullified because of commercial activities. ${ }^{108}$

4a. A stringent standard for successorship in subcontracting creates inequality between employees working in core sectors of the business and employees working in periphera sectors, the transfer of which will not give rise to a finding of successorship under a narrower rule. ${ }^{110}$

5a. The broader rule pays special attention to continued employment and similarity of functions, and rightly so, because the relevance of the business to the employees is based on the work it provides. ${ }^{12}$
$2 \mathrm{~b}$. The narrower rule marking certain elements as fatal to a successorship claim is not excluded by the wording of successor rights provisions and may thus be implied by purposive interpretation. ${ }^{107}$

3b. It is unreasonable to expect a broader rule that protects jobs instead of merely protecting bargaining rights, because that exceeds the purpose of successor rights provisions. ${ }^{109}$

$4 \mathrm{~b}$. Unions can minimize the damage done by the narrower rule by seeking region-wide instead of single workplace bargaining units in a subcontracted part of a business. ${ }^{111}$

$5 \mathrm{~b}$. The broader rule attaches too much importance to work as a determinative element of the business and unduly grants unions an "absolute right of property in the work performed by [their] members." 113

106. Ajax, Div Ct, supra note 63 at para 28, citing UFCW v Parnell Foods Ltd, [1992] OLRB Rep 1164 at para 91, 17 CLRBR.

107. Bibeault, supra note 16 at para 160-62.

108. Ajax, Div Ct, supra note 63 at para 21, citing Lester (WW) (1978) Ltd v United Association of Journeymen and Apprentices of the Plumbing and Pipefitting Industry, Local 740, [1990] 3 SCR 644 at 409, 76 DLR (4th) 389; Metro-Parking, supra note 34 at para 20.

109. Canada Post Corporation and Nieman's Pharmacy $v$ Canadian Union of Postal Workers (1989), 4 CLRBR (2d) 161 at para 52, 1989 CarswellNat 854 (WLNext Can) [Nieman's Pharmacy]. I have not summarized the Nieman's case above for brevity's sake, but I include it here because it contains arguments that can be transposed to other legal questions and fit well in my table. This case dealt with the transfer of some postal business by Canada Post to a pharmacy and involved the legal question of whether good faith subcontracting can ever trigger successor rights provisions.

110. Ivanhoe inc c Travailleurs \& travailleuses unis de l'alimentation $\&$ du commerce, section 500, [1999] RJQ 32 at para 138, 1998 CarswellQue 4709 (WLNext Can) (QCCA) LeBel J [Ivanhoe, QCCA].

111. Bibeault, supra note 16 at para 222.

112. Accomodex, supra note 37 at para 59.

113. Metro-Parking, supra note 34 at para 36, citing British American Bank Note Co Ltd, [1979] OLRB Rep Feb 72. 
6a. The narrower rule put forward by management is bad for employers, because the elimination of bargaining rights provokes new organizing campaigns and potential labour conflicts. ${ }^{114}$

7a. The broader rule accounts for the fact that the mischief addressed by successor rights (the undermining of bargaining rights) is present even when there is no strong "nexus" or "legal relation". ${ }^{116}$
6 b. The broader rule put forward by the union, in turn, hurts the employees by unduly extending bargaining rights and circumventing the certification process, thus preventing employees from expressing their wishes in a vote. ${ }^{115}$

7b. The broader rule wrongly allows successorship findings to be made in the absence of a strong "nexus" or "legal relation" between alleged successors. Thus, under the broader rule, routine commercial activities such as losing a contract to a competitor might lead to an undue finding of successorship. ${ }^{117}$

\section{TABLE 2: EMPLOYER-INITIATED ARGUMENT PAIRS}

\section{Arguments for a Narrower Interpretation of Arguments for a Broader Interpretation of} Successor Rights Provisions

8a. The broader rule goes against the legislative intention that certification attach to a single employer. ${ }^{118}$

9a. The narrower rule preserves the employer's "legal freedom to dispose of its business." 120

10a. The broader rule leads to unpredictable results, creating legal (and economic) uncertainty. ${ }^{122}$

\section{Successor Rights Provisions}

8 b. On the contrary, the broader rule accounts for the fact that the legislature intended that the instrumental test be adapted to "the reality of the business practices it is addressing." 119

9b. The narrower rule does not account for the fact that, in light of the purpose of successorship provisions, "[o]ne should not expect commercial law considerations to be paramount"121 in the interpretation of the provisions.

10b. On the contrary, the broader rule contributes to legal (and economic) certainty by ensuring the "stability of certifications." ${ }^{23}$

114. Bibeault, supra note 16 at para 146; Metro-Parking, supra note 34 at para 46.

115. Nieman's Pharmacy, supra note 109 at para 37.

116. Metro-Parking, supra note 34 at para 46.

117. Ibid at para 36, citing NABET v Radio CYJC Ltd et al (1978) 1 CLRBR 565 [NABET].

118. Bibeault, supra note 16 at paras 159-62.

119. Ivanhoe, supra note 12 at para 92.

120. Metro-Parking, supra note 34 at para 20.

121. Accomodex, supra note 37 at para 52.

122. Bibeault, supra note 16 at para 218.

123. Ivanhoe, QCCA, supra note 110 at para 186. 
11a. The broader rule is overbroad and leads to unwarranted findings of successorship in situations where there is no continuity of the business. ${ }^{124}$

12a. The broader rule extends successor rights to cases where it would be unfair or unpractical to transfer the collective agreement as well as the certification. Thus it extends beyond 'real' cases of successorship. ${ }^{126}$

13a. The broader rule creates a perverse incentive not to engage in a given economic activity (e.g., hiring employees or buying assets from the alleged predecessor) in order to avoid the application of successor rights provisions. ${ }^{128}$

14a. Relaxing the standard for the transfer of "part of a business" (i.e., subcontracting) does not account for the complexity and interdependence of all the components of the business, which cannot easily be separated. ${ }^{130}$
$11 \mathrm{~b}$. On the contrary, the broader rule is "flexible" and allows for consideration of the facts of each given case. ${ }^{125}$

12b. Courts always struggle with the transfer or modification of an existing collective agreement when making a finding of successorship; the broader rule is not unique in this regard. ${ }^{127}$

13b. The narrower rule encourages employer schemes to undermine bargaining rights. ${ }^{129}$

14b. The scope of successor rights should be broadened to account for new economic realities (corporate restructuring, flexible forms of production, et cetera). ${ }^{131}$

These tables are meant to make apparent the potential interchangeability of policy arguments across many sub-questions. For a given choice between broader and narrower rules, for instance between accepting and rejecting the theory of retrocession, decision makers could rely on all the arguments presented above. Thus, they could hold that the theory of retrocession should be rejected because it leads to legal uncertainty (argument 10a), is overbroad (argument 11a), does not account for the interdependence of the various parts of the business (argument 14a), et cetera. And these arguments could be met with their opposites, i.e., that a broader rule such as the theory of retrocession contributes to legal certainty and the stability of certifications (argument 10b), is flexible (argument 11b) and accounts for the realities of the new economy (argument 14b).

124. Bibeault, supra note 16 at para 166.

125. Ivanhoe, supra note 12 at para 94.

126. Ibid at para 159 (Bastarache J, dissenting).

127. Ibid at para 11 (Arbour J, for the majority).

128. Metro-Parking, supra note 34 at para 36, quoting NABET, supra note 117.

129. Ivanhoe, QCCA, supra note 110 at para 186.

130. Nieman's Pharmacy, supra note 109 at para 41.

131. Ajax, OLRB, supra note 38 at paras 31-33; Accomodex, supra note 37 at para 75. 
The tables also reveal that purposive arguments are susceptible to many conflicting interpretations that undermine their claim to conclusiveness. As mentioned earlier, the purpose of "protecting bargaining rights" (argument 1a) can be met with the response that the relevant rule "expands rather than protects" these rights (argument $1 \mathrm{~b}$ ). As evidenced by the arguments $2 \mathrm{a}$ and $2 \mathrm{~b}$, purposive arguments related to institutional competence and the separation of powers are often no more conclusive. Claims that adopting a restrictive rule amounts to judicially rewriting the legislation (argument 2a) can be met with the contrary argument that a broad reading of the provision also amounts to judicial usurpation of the legislative role (argument $2 \mathrm{~b}$ ). Likewise, the claim that the legislature intended to attach bargaining rights to one employer (argument 8a) can be met with the claim that the legislature also intended that the concept of "employer" be contextualized in light of the facts of each case and economic context (argument 8b); to which one can answer that the facts of the case are clear as to who is the one employer to which bargaining rights should attach, et cetera. It seems that purposive arguments are unlikely to be conclusive on their own. Instead, they will probably be accompanied by a balancing of other policy arguments pertaining to the separation of powers, the expectations and legal rights of the parties, the effects of the proposed rule on economic activity or legal certainty.

My analysis of successor rights cases is meant to suggest deep normative conflicts and legal indeterminacy (in the sense of there being no 'right answer'). However, I have proposed a relentlessly practical account of legal indeterminacy and do not intend to offer much theorizing on the subject, except to say the following. I do not claim that law is always indeterminate but rather that incommensurable normative conflicts are created by the actors' legal work. ${ }^{132}$ In other words, indeterminacy can be created by the finding of a contrary argument that perfectly neutralizes another one. But of course sometimes law is determinate in the sense that one (policy) argument is more convincing because no actor marshals another equally convincing argument. It is just that whether this will happen seems wildly unpredictable, making indeterminacy an ever-present possibility. In a given situation, the parties' (or the judge's)

132. For the inspiration of this approach, see Mark Tushnet, "Defending The Indeterminacy Thesis" (1996) 16:3 Quinnipiac L Rev 339 at 347; Duncan Kennedy, "A Left/ Phenomenological Alternative to the Hart/Kelsen Theory of Legal Interpretation" in Legal Reasoning, Collected Essays (Aurora, CO: The Davies Group, 2008) 154 at 154-57 [Kennedy, "Left/Phenomenological"]; Joseph William Singer, "The Player and the Cards: Nihilism and Legal Theory” (1984) 94:1 Yale LJ 1 at 21-22. 
efforts may produce one right answer, or they may not. This phenomenological approach to indeterminacy focuses not on the immutable nature of law but on actors' experience of it as the "reality" to be studied. ${ }^{133}$ Hence, one could see my analysis above as itself creating indeterminacy and demonstrating the possibility thereof, by systematically pairing up arguments that neutralize each other (just as Llewellyn famously did with the canons of statutory interpretation). ${ }^{134}$ This is enough to flesh out my claim that the cases I explored evidence deep, potentially intractable normative conflicts.

I do want to stress again that the approach to labour law doctrine I have exemplified here is not based on a representative sample of cases. That is, I do not claim to have assembled a sample of cases that share characteristics that are generalizable to all of union successor rights law, let alone to labour law as a whole. Such a claim would in my view be untenable. For example, my analysis would not be more representative of Canadian successor rights law even if I had chosen, say, twelve cases instead of six, cases from four provinces instead of two, or cases that cover a shorter time period. It seems to me that one can never claim to have amassed a sample of cases representative of all those that are out there. Rather than an empirical demonstration in the strict sense, I have sought to provide an illustration of the way in which a small group of cases can be arranged doctrinally so as to make apparent (or, to put it in more phenomenological terms, to create) incommensurable conflicts of legal argument. I do think that my arranging of the cases in a pyramidal form of sub-questions dealing with the legal sufficiency of certain elements illustrates how this analysis can be applied to any successor rights case dealing with whether there is a "sale of business" in a given instance. The whole point of my reframing of case-by-case rule applications as logically and chronologically interrelated questions of law is to suggest that such an extension is possible. However, this is the most I can achieve given my space constraints, and by necessity my analysis falls short of an empirical demonstration based on a scientifically sound sample of cases. Instead, the reader should see my analysis as an illustration of what can be achieved when we abandon the old legality approach and look for intractable policy conflicts in labour law, and as an invitation to incorporate this method in teaching and doctrinal research.

On a related note, I have to leave for later exploration the suggestion that this framework could be extended to other labour law questions such as the elements required to make out just cause for dismissal, legitimate business reason for a layoff,

133. For the most elaborate and best known discussion of indeterminacy in phenomenological terms, see Kennedy, "Left/Phenomenological," supra note 132.

134. Llewellyn, supra note 20. 
European-style proportionality of strike action and constitutional protection of strikes depending on their objectives ("purely political" or otherwise), North American-style unfair labour practices and bad faith bargaining, et cetera. Suffice it for now to mention that I think my model, based as it is on policy argument in favour of narrower and broader rules on the legal sufficiency of certain elements under a given test, is capable of being extended to many other areas of labour and employment law writ large. Again, this is a call to take up this kind of analysis and constantly work with the hypothesis that, in labour and employment law, there is no single set of rules that is responsive to pragmatic and socially purposive reasoning, but rather a hodgepodge of unexplainable policy choices that shape the economy at any given point and that could easily be redesigned entirely to favour different policies and material interests.

\section{CONCLUSION}

In this article, I have analyzed a series of Canadian cases on successor rights in which labour adjudicators and courts have dealt with the question of whether bargaining rights should be transferred to another business entity in the context of sales, restructuring, and subcontracting. Parts I and II summarized classic successor rights cases from Ontario and Quebec dealing with the instrumental or organic approach to the meaning of "sale of a business," according to which there needs to be a transfer of the business as a whole and mere similarity of functions does not suffice. In Part III, I argued that these cases are best understood as a series of interdependent legal holdings as to what elements should be per se insufficient, not merely as the application of the instrumental approach to a particular fact pattern. In Part IV I read together the arguments used to justify different legal holdings and demonstrated that each policy argument can be raised in many different cases, rendering purposive argument inconclusive. I attempted to cast doubt on a particular legal theory, the old legality, according to which labour law is made not through conventional legal reasoning but through non-legal and ad-hoc applications of loose legal criteria in light of purposive reasoning. Based on my account of conflicting legal policy arguments, I argued that the old legality paradigm should be abandoned in favour of an approach that embraces the incommensurable normative and legal conflicts that pervade the collective bargaining regime and the economy it structures.

One might object that the old legality is a strange target because it has, to some extent, been displaced as the intellectual paradigm of choice in light of the perceived deficiencies of the post-war labour regimes in the new economy. 
While labour lawyers, scholars, and courts have by and large stuck to the old legality, ${ }^{135}$ some sophisticated labour lawyers have been busy outlining alternative normative frameworks, sometimes based on human rights, capabilities theory, or economic efficiency. ${ }^{136}$ However, many other scholarly takes on the new economy merely propose new modes of enforcement of labour laws while in fact implicitly or explicitly maintaining the old legality as the governing approach. ${ }^{137}$ It thus seems as if the old legality will not be easily displaced and is deserving of critical scrutiny.

The need for critical scrutiny is reinforced by the fact that the old legality and its rationalization of law according to non-legal, expert perceptions of the good of society, in a context where the existing labour law regimes are what is rationalized, may well have the effect of reinforcing the status quo. It may do so by supplying an overarching normative justification for existing legal regimes that validates them and holds them to be more than they really are, i.e., ad-hoc and often unexplainable compromises between various conflicting policies, and ultimately between various material interests. I rely here on Hans Kelsen's analysis of the legitimating function of natural law, by which he also meant the "sociological jurisprudence" 138 from which labour law's old legality was born. For Kelsen, law is a positive system of coercion ordering various contradictory interests, and attempts to justify it by reference to any outside criterion of "justice" legitimize the order in place:

\begin{abstract}
Seen from the standpoint of rational cognition, there are only interests and thus conflicts of interests, which are resolved by way of an ordering of interests that either satisfies the one at the expense of the other, or establishes a balance, a compromise between the opposing interests. That only one ordering of interests has absolute value (which really means, 'is just') cannot be accounted for by way of rational cognition. ... Only positive law is given to cognition. ... The less one strives to separate clearly the positive law from justice, and the more indulgent one is toward the lawmaker's efforts to have the law also accepted somehow as just, the more one lends support to the ideological bias that is characteristic of classical, conservative natural law theory. What matters there is less the cognition of prevailing law than a justification of it, a transfiguration, achieved by showing that the positive law is simply the emanation of a natural or divine order or of a system of reason - the emanation of an absolutely 'right', just order. ${ }^{139}$
\end{abstract}

135. See supra notes 11-18.

136. See generally, supra notes 25-27.

137. Supra note 24.

138. Hans Kelsen, Introduction to the Problems of Legal Theory (Oxford: Clarendon Press, 1934; 1992) at 41 [Kelsen].

139. Ibid at 17-18 [emphasis added]. 
I should mention that, like Kelsen's view (and that of many critical legal theorists), ${ }^{140}$ my view of sociological jurisprudence as legitimizing the status quo by rationalizing the positive law depends on the claim that said positive law is not amenable to rationalization because of incommensurable conflicts between "a number of decisions ... of equal standing" on each legal question (hence my emphasis on indeterminacy). ${ }^{141}$ In short, it is because the status quo does not rest on logical closure or coherence that the old legality's rationalization legitimizes it. It seems very plausible that this rationalization would have a moderating effect on the law reform avenues we think are possible and worth pursuing.

In the context of the rolling back of the post-war labour law regimes (often under crisis-induced austerity), preserving the status quo and being "indulgent... toward the lawmaker's efforts"142 might be thought to be a good thing. But I think on balance such a rationalization through the old legality paradigm does more harm than good. In recent decades, inspiring research has shown that the post-war North American labour law model and its core collective bargaining component offer very partial protection that is often structurally skewed in favour of certain interests at the expense of others. Particularly, scholars have underlined the post-war regime's shortcomings with respect to women, ${ }^{143}$

140. See the following analyses of the legitimating effect of denying intractable normative conflicts and legal indeterminacy: Alan Freeman, "Legitimizing Racial Discrimination through Antidiscrimination Law: A Critical Review of Supreme Court Doctrine" (1978) 62:6 Minn L Rev 1049; Peter Gabel \& Paul Harris, "Building Power and Breaking Images: Critical Legal Theory and the Practice of Law" (1982-83) 11:3 NYU Rev L \& Soc Change 369; Gerald Frug, "The Ideology of Bureaucracy in American Law" (1984) 97:6 Harv L Rev 1276; Robert W Gordon, "Some Critical Theories of Law and Their Critics" in David Kairys, ed, The Politics of Law: A Progressive Critique, 3d ed (New York: Basic Books, 1998) 641 at 647-51; Duncan Kennedy, "The Structure of Blackstone's Commentaries" (1979) 28:2 Buff L Rev 205 at 217-18.

141. Kelsen, supra note 138 at 80.

142. Ibid at 18 .

143. See Judy Fudge, "Reconceiving Employment Standards Legislation: Labour Law’s Little Sister and the Feminization of Labour" (1991) 7:1 J L \& Soc Pol'y 73 at 87-88; Joanna Conaghan \& Kerry Rittich, "Introduction: Interrogating the Work/Family Divide" in Joanne Conaghan \& Kerry Rittich, eds, Labour Law, Work, and Family (Oxford: Oxford University Press, 2005) 1. 
ethnic minorities, ${ }^{144}$ self-employed persons ${ }^{145}$ and a whole host of sectors of the economy not amenable to unionization under such a local bargaining unit model. ${ }^{146}$ European labour law systems also have their own inadequacies. ${ }^{147}$ These shortcomings are exacerbated when Northern labour law regimes are transposed in the Global South. ${ }^{148}$ Not to mention of course that the new economy has greatly diminished the post-war model's efficacy (and eradicated it in the United States). Further, one could argue that model never went far enough in the direction of wealth redistribution anyway. ${ }^{149}$ In this context, it seems useful to underline the analytical contestability of the old legality on which these regimes rest, if only to open up the possibility for more ambitious re-regulation of work in all its forms, perhaps by tackling all the legal regimes that determine living conditions beyond labour law as traditionally conceived. ${ }^{150}$ Of course, once one lets go of the pragmatic and purposive defense of existing regimes in the name of social stability and industrial peace, other normative projects such as economic efficiency might rear their heads to replace it. ${ }^{151}$ This prospect requires one to

144. See Colleen Sheppard, "Mapping anti-discrimination law onto inequality at work: Expanding the meaning of equality in international labour law" (2012) 151:1-2 Int'l Lab Rev 1; Adelle Blackett, "Situated reflections on international labour law, capabilities, and decent work: The case of Centre Maraîcher Eugène Guinois," Liber Amicorum in honour of Katia Boustany (2007) hors série RQDI 223.

145. See Judy Fudge, Eric Tucker \& Leah Vosko, "Changing Boundaries in Employment: Developing a New Platform for Labour Law” (2003) 10 CLELJ 329 at 331-32; Brian A Langille \& Guy Davidov, "Beyond Employees and Independent Contractors: A View from Canada" (1999) 21 Comp Lab L \& Pol'y J 7 at 16-17 [Langille \& Davidov].

146. Langille \& Davidov, ibid; Adelle Blackett \& Colleen Sheppard, "Collective Bargaining and Equality: Making Connections” (2003) 142:4 Int'l Lab Rev 419 at 422-27.

147. See Diamond Ashiagbor, "Unravelling the Embedded Liberal Bargain: Labour and Social Welfare Law in the Context of EU Market Integration" (2013) 19:3 Eur LJ 303 at 308-10; David M Trubek \& James S Mosher, "New Governance, Employment Policy, and the European Social Model" in Jonathan Zeitlin \& David M Trubek, eds, Governing Work and Welfare in a New Economy: European and American Experiments (New York: Oxford University Press, 2003) 33 at 35.

148. See Adelle Blackett, "Beyond Standard Setting: A Study of ILO Technical Cooperation on Regional Labor Law Reform in West and Central Africa" (2011) 32 Comp Lab L \& Pol'y J 443 at 461-64; Alvaro Santos, "Labor Flexibility, Legal Reform, and Economic Development” (2009) 50 Va J Intl L 43 at 68-73 [Santos]; see generally Tzehainesh Teklé, Labour Law and Worker Protection in Developing Countries (Oxford: Hart Publishing, 2010). 149. Klare, supra note 10.

150. See Kerry Rittich, "Fragmented Work and Multi-level Labour Market Governance: Informality, Crisis Policy and an Expanded 'Law of Work'” in de Búrca, Kilpatrick \& Scott, supra note 24 at 185.

151. See the work cited in supra note 27. 
seriously address these projects and the extent to which they might put a brake on redistributive projects, an endeavor for which there already exists a solid repertoire of critical legal analyses (hint: I think economy efficiency concerns are sometimes legitimate but very often overblown). ${ }^{152}$ However, such an intellectual adventure seems well worth the risk if, in this new economy, we are to have a legality that can carry forward our wildest longings for redistribution and solidarity.

152. See generally Santos, supra note 148; Duncan Kennedy, "Cost-Benefit Analysis of Entitlement Problems: A Critique” 33:3 Stan L Rev 387 (1981); Nicholas Mercuro \& Steven G Medema, Economics and the Law: From Posner to Post-Modernism (Princeton: Princeton University Press, 1997); Kerry Rittich, Recharacterizing Restructuring: Law, Distribution and Gender in Market Reform (The Hague: Kluwer Law International, 2002). 